\title{
Cultural Heritage and Translation: Rethinking Website Information of Palaces
}

\author{
Seung-jae Lee \\ Kyung Hee University
}

\begin{abstract}
Internet websites, as major media for information technology, is becoming an important vehicle for transferring information as well as advertising products. This paper aims to study website information mainly concerned with cultural heritages, that is, palaces. Incorporating culture and advanced technology, the websites contains information of hybrid context. Five palaces of the world were selected from the portal research and reviewed based on the extra-linguistic, intralinguistic and inter-linguistic aspects. The extra-linguistic aspect is compared with regard to the three major categories of structure, text, and technology. The intra-linguistic aspect is concentrated on the text content. The inter-linguistic aspect is concerned with translation. Reviewing the English translation of palaces ensures the cultural translation as well as the role of translators. Consequently, websites expand the boundary of tourism communication, from spoken to written.
\end{abstract}

Keywords: tourism communication, website information, extralinguistic, intra-linguistic, and inter-linguistic aspect 
74 Cultural Heritage and Translation

\section{Introduction}

Palaces, as a cultural heritage, are a unique legacy from the perspective of tourism. As a main part of cultural tourism in the 21st century, it provides tourists with a venue for a mental journey and the opportunity to experience the royal life style and privilege of the royal family through transcendental coincidence of the place. With the lapse of time, the restricted place only for the selected few royal families, gives way to the general publicity, and the isolated haughtiness of the past is replaced with humble cultural legacy of the present. Therefore, visiting palace is not just a romantic longing for a royal experience, but an appreciation of cultural legacy.

The palace is a royal residence, as well as a seat of government or a religious centre. Palaces have existed since ancient times, and offer a tangible insight into the life of the royalty and culture.

\section{Palace as a Cultural Heritage ${ }^{1}$}

Culture has many aspects, and the term 'heritage' stands for everything that is inherited, including structures, objects, images, ideas, sentiments, and practices. (The Concise Oxford Dictionary of Archaeology 2002) According to UNESCO (2008), ${ }^{2}$ palaces belong to the tangible and immovable cultural heritage. ${ }^{3}$

\footnotetext{
${ }^{1}$ The word palace is originally derived from the Palatine Hill in Rome (Britannica Concise Encyclopedia). The original palaces on the Palatine Hill were the seat of the imperial power (wikipedia), and the palace means government, but later it got the general sense of splendid dwelling place from 1387 (Harper 2001).

2 The term "cultural heritage" encompasses several categories of heritage: Cultural heritage; Tangible (movable/ immovable/ underwater); Intangible (UNESCO 2008).

${ }^{3}$ Cultural heritage ("national heritage" or just "heritage") is the legacy of physical artifacts and intangible attributes of a group or society that are inherited from past generations, maintained in the present and bestowed for the benefit of future
} 


\subsection{Palace in the 21st Century}

As the residence of the king, the palace was the center of power, and the imperial polity. As a royal residential area, the magnificent buildings in the palace are the most representative vestige of the era, ${ }^{4}$ and the greatest esthetic achievements of the architects and engineers of that age. The palace housed administrative offices and living quarters; the palace is the secluded place from the hectic life of modern city. It is surrounded by the high walls, bushes and plants. The landscape of the palaces is spacious with palace gardens, water fountains, various plants and flowers, and oddly shaped stone statues. Inside the palace there are many stylish and magnificent architectures, with grand pillars, decorative ornaments, various masterpieces, and elaborate artifacts, etc. Luxury and solemnity make the palace unique in the contemporary life and attract the contemporaries and tourists. Recent statistics shows that the number of visitors at Kyungbokgung palace is 3,115,169 (1,191,250 nonKorean visitors) (Cultural Heritage and Legacy of Korea 2009). ${ }^{5}$

\subsection{Tourists and Palaces}

Traveling presupposes openness to the unknown world, and experiencing new culture serves a momentum to expand understanding of other culture.

Like Pyramids for the ancient tombs, temples and monasteries for religious rituals, the palace is a cultural complexity of history,

generations. (wikipedia) Physical or "tangible cultural heritage” includes buildings and historic places, monuments, artifacts, etc.

${ }^{4}$ The palaces are relatively large buildings of that time and now turned into its usage as congress buildings, museums, government buildings or hotels, etc.. Some palaces keep its original functions as a government seat or residential area.

${ }^{5}$ Palaces are the most representing tourist attraction and the most frequently visited place for international tourists (Cultural Heritage and Legacy of Korea 2009). 
76 Cultural Heritage and Translation

architecture, philosophy, ect. A recent article reported that UNESCO reevaluated royal tombs in Chosun and added them on the UNESCO cultural heritage list, due to its cultural, philosophical, and architectural value (http://news.chosun.com 2009.6.27).

Palaces are mystic spaces that were accessible to only the royal family, and are the cultural complex of history, philosophy, arts, and architecture, and the living museum with natural atmosphere.

Therefore the palaces remain as the venue of interest in spite of transition of time and place; the palace, as a total cultural complexity, is the symbol of power, and the place of mystery. This paper will study the palaces, especially the website information of palaces in order to examine the effect of cultural translation and the role of translators.

\section{Study}

\subsection{Selection of Palaces}

To objectively select the research subject, data from two credible portal sites were drawn for the making of the final list, ${ }^{6}$ that is, Versailles in France, Buckingham Palace in England, Forbidden City in China, Nagoya Castle in Japan, and Kyungbokgung Palace in Korea. ${ }^{7}$ By visiting and examining each palace's official website, consider the structure and contents of the websites.

\footnotetext{
${ }^{6}$ Travel Channel provides "Best Royal Palaces to Visit” with Versailles, The Grand Palace, Tower of London, Topkapi Palace, Buckingham Palace, Iolani Palace, and Jai Mahal Palace. Another source was "Hillman's Wonders of the World” with Taj Mahal, Forbidden City, Potala Palace, Versailles, Kremlin, Topkapi Palace and Chambord Chateau.

7 Palaces and websites considered in this paper are as follows: Versailles www.chateauversailles.fr/en Buckingham Palace www.royal.gov.uk/ Forbidden City www.dpm.org.cn/ Nagoya Castle www.nagoyajo.city.nagoya.jp/13_english/ Kyungbokgung Palace www.royalpalace.go.kr/html/eng.
} 


\subsection{Analysis of Websites}

According to TIA (Travel Industry Association of America), 67\% of American travelers used the internet for travel information. In order to fulfill the needs of the internet-user and increase one's desire to travel, the quality and construction of a website should be considered. Analyzing information provided by the website, it is specified into three categories, that is, the structural aspect, the contextual aspects, and the technical aspects. ${ }^{8}$

\subsubsection{Structural Aspects}

The layout of the websites on the palaces is preset with the palace information, which generally consists of (1) the ground plan of the palace and the interior, (2) accommodation/transportation, (3) attractions, (4) events, (5) tour information (timetables, means to tour, fees, etc), etc., and makes a menu template. Each navigation bar in the menu is linked to different web pages with clicks on mouse-over to facilitate viewer's search through the website. ${ }^{9}$

\subsubsection{Text}

Text in the websites has been the top priority. In analyzing the text, (6) authenticity for the reliable information (7) attractiveness for the reader's expectation (8) efficiency for searching necessary information (9) capacity for the reasonable amount of information (1) accuracy for the spelling mistakes will be considered. Especially,

\footnotetext{
${ }^{8}$ The structural aspect will be co-related with Navigation, the contextual aspect with Text, and the technical aspect with Usability under the information architecture of websites.

${ }^{9}$ Navigation on a website is achieved by a collection of links (text/ images/ flash/ java applets) that form the Website Navigation Menu or the Website Navigation Bar.
} 
the texts considered in this paper are written in English or translated into English. Therefore the text analysis here should be involved in translation, and details about the content analysis regarding translation will be discussed in the section 3.3.

\subsubsection{Technical Aspects}

The term usability is mostly used to denote the technical aspects, for example, information downloading time, access to the external links, etc. In this paper (11) graphics, which are mostly web images (12) video (VR), which is youtube video or virtual tour program for the palace (13) audio, which is sound system (14) link sites, which show the related sites (15) downloading, will be considered as the criteria for usability.

\subsection{Translation and Website Information}

The official websites of cultural heritage of palaces provide the language services. Naturally the translated version of the given information into the target language is shown on the website menu. This paper is mainly concerned with the translation of the source language into English. ${ }^{10}$ Palaces are the complex collection of history, social structure, religion, traditional customs and usage, and cultural meanings are intricately woven into the texture of the language. Therefore the cultural elements should be transmitted into the translation process.

\footnotetext{
${ }^{10}$ Versailles in France will be the model for the palace website, which is most popular in the world. Buckingham Palace in England will provide the model for the source language. The English translation of Kyungbokgung Palace was analyzed and provided distinctive characters found in the analysis. With these in mind, Forbidden City in China, and Nagoya Castle in Japan will be analyzed.
} 


\subsubsection{Website Information as a Text for Translation}

Translation of the website information on the palace is surely a process of the cultural translation. As we see in the previous section, the given information on the website is different from the literary translation. Because of the unique properties of websites, the given information is subject to the space limit and the website information should be attractive to catch the reader's attention. Therefore, the text is neither literary ${ }^{11}$ nor scientific (technical), but is hybrid. The reason is that, on the one hand, the main purpose is delivering message as an outcome of advanced technology, and on the other hand, the content in the website is culture, the main topic of literature. Therefore, translating the website information is not the proper literary translation but a quasi literary translation.

\subsubsection{Website Information and Cultural Translation}

Translation is an activity that "inevitably involves at least two languages and two cultural traditions.” (Toury 1978: 200; 1995). Knowing the source and target languages and cultures is not enough, but the translator must also work out the correspondences and equivalences between them (Straight 1981: 41)

The translation process consists of three stages (1) analysis of the ST (source text); (2) problem-solving; (3) re-verbalization where the translator is the operator.

There are various definitions of culture, but concerned with language and translation, Newmark defines culture as "the way of life and its manifestations that are peculiar to a community that uses a particular language as its means of expression” (1988: 94). Therefore each language has its own culturally specific features, and

\footnotetext{
${ }^{11}$ One of the main goals of literary translation is to initiate the target-language reader into the sensibilities of the source-language culture.
} 
translating the source language (SL) into a suitable form of target language (TL) is part of the translator's role in the cultural translation.

The cultural implications in the website information are various from lexical content and syntax to ideologies and ways of life in a given culture. Cultural translation requires a certain level of linguistic competence as well as cultural understanding. Especially the text given in the websites of palaces targets the educated, middle-class in Newmark's (1988: 13). In this sense, translating is a process of responding to the potential reader's expectation. In translating a cultural implication, the question of relevance is given to the projected readers; translating from the source language to the target language importance should be given to the culture of the target language. Thus the translator has to be aware of two cultures, and the translator has to deal with the cultural aspects implicit in a source text (ST) and find the most appropriate outputs in the target language (TL).

\subsubsection{Website Translation and Kyungbokgung Palace}

Translation is not simply replacing words with similar meanings but of finding appropriate ways of saying things in another language. As an official website, the translated information on the palace is proper to understand the palace, the architecture, the lifestyle, customs and culture. A comparison of the Korean with the English version of information shows some distinctive properties, which is very similar to the literary translation; the translator's personal knowledge and attitude toward the palace is reflected on the translated version. Regarding the cultural translation of Kyungbokgung palace, Lee (2009) points out the loss of formality in the process of translation, the translator's personal addition of the cultural knowledge, or arbitrary omission of less important parts. The translator's intention shown in the website translation is versed by Gutt's (2000) relevance. 
The following are to be considered in the cultural translation:

1. Proper noun as a linguistic cultural element resists translation; therefore its evocative value is lost.

2. Formal terms referring to the parts of palaces in Eastern culture are substituted to the informal language and the idea behind the king's official place (dignity or respect) would be lost.

3. Symbols or ornaments behind customs and tradition pose difficulty in finding the proper match outside culture. Awareness of history is essential for the translator to deal with historical events occurred in the palace.

4. Religious elements, myths, legends, and the like are major components of any culture. However the website of palace does not deal with culture that requires in-depth knowledge, but the basic cultural information.

Cultural transfer requires a two-way approach. It is concerned with the source text and with target readers. Linguistic competence of vocabulary and grammar is not sufficient. Translator is building a bridge between two and he/she should be familiar with one's own culture and be aware of the source-language culture and transmit this special cultural quality from one language to another, and eventually create equivalence by the judicious use of resources.

\section{Text Analysis}

R. Jakobson (1971) distinguished intra-lingual translation, interlingual translation and inter-semiotic translation. ${ }^{12}$ Following Jakobson's

${ }^{12}$ Inter-lingual translation within a system of signs is related to paraphrasing, changing of genres and discourses. Inter-lingual translation means interpretation of verbal signs with the verbal signs of another language and is thus translation in 
classification, Toury differentiates between two types of translation: intra-semiotic translating and inter-semiotic translating. Intersemiotic translating involves translating from language to nonlanguage. Intra-semiotic translation can be divided into two subtypes: intra-systemic translating and inter-systemic translating. Intra-systemic translation corresponds to Jakobson's intra-linguistic translation and inter-systemic translation answers to inter-linguistic translation (Toury 1986).

Regarding cultural translation, a further extension was done by Eco (2001), where translation is a species of the genus interpretation, governed by certain principles proper to translation (Eco 2001: 80). Here we have interpretation by transcription, intra-systemic interpretation, and inter-systemic interpretation. With the same line of logic, this section will divide website information into three parts: extralinguistic aspect, intra-linguistic aspect, and inter-linguistic aspect.

\subsection{Extra-linguistic Aspect: Website Evaluation}

As an extra-linguistic part of websites, the palaces will be examined from three aspects, that is, structure, text and technology. Each major category is subdivided and makes a grid of 15 slots as shown in table (1).

According to the fifteen evaluation criteria provided in Table 1, France's Versailles is the richest in content and structure. The websites of China's Forbidden palace and Japan's Nagoya Castle have difficulties in accessing them. As a working palace, England's Buckingham palace open only limited sections, far insufficient to meet the curiosity of tourists, thus becoming merely nominal tour spots. Korea's Kyungbokgung palace website, with comparison to other palaces, shows the satisfactory result with structure, text, and technology, promising a positive effect on tourism.

the ordinary sense. Inter-semiotic translation or transmutation means interpretation of the signs of a sign system with the signs of another sign system. 
Table 1. Website Evaluation: Palaces ${ }^{13}$

\begin{tabular}{|c|c|c|c|c|c|c|c|c|c|c|c|c|c|c|c|}
\hline \multirow{2}{*}{ Palace } & \multicolumn{5}{|c|}{ Structural Aspect } & \multicolumn{5}{|c|}{ Content } & \multicolumn{5}{|c|}{ Technical Aspect } \\
\hline & (1) & (2) & (3) & (4) & (5) & (6) & (7) & (8) & (9) & (10) & (11) & (12) & (13) & (14) & (15) \\
\hline Versailles & 0 & o & 0 & o & 0 & 0 & 0 & 0 & o & 0 & 0 & 0 & o & 0 & o \\
\hline $\begin{array}{l}\text { Buckingham } \\
\text { Palace }\end{array}$ & $\mathrm{x}$ & $\mathrm{x}$ & 0 & 0 & 0 & 0 & 0 & $\mathrm{X}$ & 0 & 0 & 0 & 0 & 0 & 0 & $\mathrm{X}$ \\
\hline $\begin{array}{c}\text { Forbidden } \\
\text { City }\end{array}$ & 0 & $\mathrm{x}$ & 0 & 0 & o & 0 & 0 & $\mathrm{x}$ & 0 & 0 & o & 0 & $\mathrm{x}$ & 0 & 0 \\
\hline Nagoya Castle & $\mathrm{x}$ & $\mathrm{x}$ & 0 & 0 & 0 & 0 & 0 & $\mathrm{x}$ & 0 & $\mathrm{x}$ & 0 & $\mathrm{x}$ & $\mathrm{x}$ & $\mathrm{x}$ & $\mathrm{x}$ \\
\hline Kyungbokgung & o & 0 & 0 & o & o & o & 0 & 0 & o & 0 & 0 & 0 & 0 & 0 & 0 \\
\hline
\end{tabular}

(1) inside map (2) accommodation/transportation (3)attractions (4) events

(5) tour (6) authenticity (7) attractiveness (8) efficiency (9) capacity

(10) accuracy (11) graphics (12) video(VR) (13) audio (14) link sites (15) download

Based on this, we may say that an important quality of the website is quick downloads and browser friendliness. A website should not be overloaded with complex functions and information. The use of multi-media in the websites can give a potential tourist a travel 'preview.' Tourism website needs a range of e-services related to travel needs, such as currency converters, weather forecast reports, local transport schedules and fares, accommodation, local attractions, event information, etc.

\subsection{Intra-linguistic Aspect}

The text of a website is like a wellspring of information. Different from the extra-linguistic aspect, which is a broader concept and more related to the technology or website design, etc., the intra-linguistic one is meticulous and is more concerned with

${ }^{13}$ The evaluation was tested by 10 surveyors, whose majors are tourism English. The surveyors' English level is high enough to read the information and web browsing. 
language or communication. The following are the properties shown in the websites:

(1) Information given in the palace websites is credible, since it is administered by the official institute.

(2) Information given in the palace websites should be neat and attractive as it is in the nature of the industry. Multimedia is an important feature to catch the viewer's attention.

(3) Information given in the palace websites should be efficiently arranged to find the proper information.

(4) In terms of information amount, the website of Versailles shows an extensive amount, but the other palaces are reasonable to understand.

(5) Information given in the palace websites is accurate in the way that minor spelling mistakes are nearly nonexistent.

\subsection{Inter-linguistic Aspect and Translation}

Inter-linguistic aspect of palace websites corresponds to the process of the cultural transmission or the cultural translation. The websites considered in this paper are the English translation from the original text. The website of Kyungbokgung palace is a translation from Korean to English, Nagoya Castle is from Japanese to English, and Forbidden City from Chinese to English.

Each translation of the given information is compared by the natives. Here is what needs to be considered in each translation:

1. Incorrect translation or spelling mistakes

2. Historical or cultural details

3. Translator's omissions or additions

\subsubsection{Kyungbokgung Palace in Korea}

The text of the website has many subdivisions and has many 
links branched like blood vessels. As source of information, the web content should be consistent, concise, and understandable. As a cultural heritage, the websites of palaces require awareness on the historical facts or figures, and understanding of world culture.

The most distinctive characteristic found in the English translated version of Kyungbokgung palace is the translator's involvement into the resulting text. On the one hand, the translator gives short note on the given cultural items or historical facts e.g. 임진왜란 $\rightarrow$ the Japanese Invasions in the late 16th century, 십장생 $\rightarrow 10$ signs of longevity (sun, mountain, water, stone, cloud, pine, herb of eternal life, turtle, crane and deer). And describing the architectural style, the traditional measuring unit is converted into the universal measuring system.

On the other hand, the translator omits some parts of the original text or left un-translated. It happens only under the circumstance of the translator's decision. This is the way that the translator accommodates the cultural implications in the website translation of the palace. $^{14}$

\subsubsection{Nagoya Castle in Japan}

Websites in Japan are mostly written in Japanese, and the translated versions into English are not very common. Finding a website provided in Japanese as well as in English is not easy. The Nagoya Castle is the only one to make a comparison between Japanese and English. ${ }^{15}$

In the English translation, translator's arbitrary involvement is frequently found. Especially the long and complicated explanation

\footnotetext{
${ }^{14}$ For more information, see Lee (2009).

${ }^{15}$ Although Osaka Castle is the most famous, the website information provided in Japanese is not connected with English counterpart. Each one uses the same picture, but the explanation is not made by translation. Other castles do not provide the proper English explanation.
} 
86 Cultural Heritage and Translation

of history is cut and deleted. The cultural things are often omitted in the middle of the text. Also the translator's addition is often found when it comes to the cultural symbols or things like tea ceremony.

e.g. 辰巳櫓ともいわれ、(1)その規模、構造は西南隅櫓 と同じですが「落?間」の破風の形を異にしています。 この櫓は創建?時の姿を?えるもので、鬼瓦などに(3)葵 の紋が見られます。

Southeast Tower(Important Cultural Asset): This tower is also called Tatsumi Tower (2)tatusmi refers to the southeast). This tower survived the original castle. The symbol of (3) a hollyhock (crest of the Tokugawa family) can be seen on the ridge-end tiles.

In the English translation, the underlined part (1) is not translated. (2) tatusmi refers to the south-east is the translator's additional information. (3)葵の紋 is a symbol and the cultural meaning is added by the translator.

Strangely, spelling mistakes found several times. ${ }^{16}$

As we see in the Korean-English translation, the translator's active involvement is ensured by the Japanese-English translation. Therefore, the cultural translation requires the translator of the historical as well as cultural knowledge.

\subsubsection{Forbidden City in China}

China's official palace homepage is well equipped with advanced technology and a variety of menu. The historical details are well explained, and most parts of the translated version of English are correct, and no spelling mistakes. However, some parts are not translated, or some parts are over-specified.

\footnotetext{
${ }^{16}$ Japanese-English translation is reviewed by NakoMari.
} 
(1) 以及陈设萨满教祭祀神堂等。 (in Qianqing gong)

(2) 清代, 坤宁宫虽仍称正宫, 但主要做为宫内萨满教祭 神的场所和皇帝大婚的洞房 The Palace of Tranquility was at once the Shamanism sacrificial hall and the imperial bridal chamber. (in Kunning gong)

(3) 自盟至清初From the Yongle(永乐) Emperor (1403-1424)

This statement (1) is not translated. The first part of this statement (2)is not translated. The statement (3) is over-specification. In Chinese explanation it is "the beginning of Ming Dynasty", but in English translation it is "Yongle Emperor (1403-1424)". Although it means the same time, most foreigners may not know "Yongle Emperor" is the first emperor of Ming Dynasty. Therefore it is an example of over-specification. ${ }^{17}$

As we see from the Chinese-English translation, the translator's involvement is obvious. Therefore the role of the translator should be considered especially concerned with cultural translation.

\subsection{Cultural Translation and Translators}

As the previous section shows, the cultural translation requires translator's linguistic proficiency as well as the translator's discretion; the outcome of translation is understood in a wider context and the role of the translator is not simply confined to the language, but is extended to the mediator, or facilitator of the language especially in the cultural translation.

The term cultural mediator is often referred to by many scholars (e.g. Bochner 1981; Steiner 1975) to define translation with respect to culture. R. Taft defines it as follows:

${ }^{17}$ Chinese-English translation is reviewed by LiuYing and DuJing. 
A cultural mediator is a person who facilitates communication, understanding, and action between persons or groups who differ with respect to langue and culture. ....the mediator must be able to participate to some extent in both cultures. Thus a mediator must be to a certain extent bicultural. (Taft 1981: 53)

In the cultural translation, the translator, a language expert serving both author and reader, plays an active role as a cultural mediator and decision maker. Translators need to be aware of TT readers' needs and to take the expectations and background knowledge of potential TT readers into account. Therefore, the translator's communicative competence includes both inter-cultural awareness and strategic or problem-solving competence. (Wilss, 1990: 26) Addition or deletion is on the translator's hand, so that the translator's responsibility toward the material is required.

\section{Conclusion}

The palace, as one of the most important cultural legacy, and sought most often, is becoming an indispensable part of cultural tourism. The palace website provides an English translation of original information for the cultural tourism and for universal accessibility. As a written text, websites are the manifestations of tourism communication.

The official website of the palace is popular for tourist information. The type of the text is hybrid; although it is dealing with the culture content proper to the literary text, the purpose of it gives tourist information. Therefore the information given is short and concise for the efficiency of delivering information. Even though the style of the text takes the strategy of non-literary text, the content dealing with is culture, mainly the royal ancestors' living 
culture, the political culture, and universal philosophy. Therefore palace is not simply a venue for tourist attraction, but the essence of royal culture.

Incorporating translation into the cultural heritage is explained by cultural translation, that is, decoding-recoding-encoding of the target culture to the receptor's culture. It is decoding the target culture, and recoding by the communication mediator (translators, interpreters, or tourist guides), and eventually encoding the receptor's culture. Through this process, a translator has to look for equivalents in the target language and exercise discretion in terms of relevance rather than word for word translation. In this way the cultural translation responds to the intended interpretation of the original.

\section{References}

Baker, M. 1992. In Other Words. NewYork: Routledge.

Bates, D. \& F. Plog. 1990. Cultural Anthropology. New York: McGraw-Hill.

Bochner, S. 1981. The Mediating Person. Boston: G.K. Hall and Co. Eco, U. 2001. Experiences in Translation. Toronto: University of Toronto Press.

Gutt, A. 2000. Translation and Relevance: Cognition and Context. Manchester \& Boston: St Jerome Publishing.

Hofstede, G. 1980. Culture's Consequences: International Differences in Work-related Values. Beverly Hills, CA: Sage.

Hong, Y. \& B. Jeng. 2000. A Comprehensive Model for Evaluating Internet Web Sites. Korea Management Science Review 17.3, 161-80.

Jakobson, R. 1971. Selected Writing Vol.II. The Hague: Mouton.

Kaplanidou, K., \& C. Vogt. 2004. Destination Marketing Organization Websites Evaluation and Design: What you need to know. New 
Marketing \& Research Paper Series 5.

Kapoun, J. 1998. Teaching Undergrads WEB Evaluation: A Guide for Library Instruction. C\&RL News 59.

Lee, S. 2009. Culture: Translation or Interpretation? Paper presented at International Conference on Translation, Seoul, Korea.

Newmark, P. 1988. Approaches to translation. New York: Prentice Hall. Reiss, K. 1989. Text-type, Translation Types and Translation Assessment. In A. Chesterman (ed.), Readings in Translation Theory 105-115. Helsinki: Finn Lectura.

Sperber, D. \& D. Wilson. 1995. Relevance: Communication and Cognition. Oxford: Blackwell

Steiner, G. 1975. After Babel: Aspects of Language and Translation. London, Oxford and New York: Oxford University Press

Taft, R. 1981 The Role and Personality of the Mediator. In S. Bochner (ed.), The Mediating Person. Boston: G.K. Hall and Co. Tierney, P. 2000. Internet-Based Evaluation of Tourism Web Site Effectiveness: Methodological Issues and Survey Results. Journal of Travel Research 39. 212-19.

Tillman, H. 2004. Evaluating Quality on the Net. Babson College, MA: Babson Park.

Toury G. 1986. Translation: A Cultural-Semiotic Perspective. In T. A. Sebeok (ed.), Encyclopedic Dictionary of Semiotics, vol. II. 1111-24. Berlin: Mouton de Gruyter.

_. 1995. Descriptive Translation Studies- and Beyond. Amsterdam: Benjamins.

Wilss W. 1990. Cognitive Aspects of the Translation Process. Language and Communication 10. 19-36.

\footnotetext{
Seung-jae Lee

Department of English Interpreting, Kyung Hee University

1 Hoegi-dong, Dongdaemun-gu, Seoul 130-701, Korea

Email: sjleeth@khu.ac.kr
}

Received in Sep, 2009; Reviewed in Sep, 2009; Revised version received in Mar, 2010 